\title{
Attenuation of municipal landfill leachate through land treatment
}

\author{
Maryam Pazoki ${ }^{*}$, Mohammad Ali Abdoli ${ }^{1}$, Abdolreza Karbassi ${ }^{1}$, Naser Mehrdadi ${ }^{1}$ and Kamyar Yaghmaeian²
}

\begin{abstract}
The treatment of municipal landfill's leachate is considered as one of the most significant environmental issues. In this study a laboratory experiment was conducted through land treatment, achieving an efficient and economical method by using Vetiver plant. Moreover, the effects of land treatment of leachate of municipal landfills on the natural reduction of organic and inorganic contaminants in the leachate after the pre-treatment in the Aradkouh disposal center are invested. Three pilots including the under-investigation region's soil planted by Vetiver plant, the region's intact soil pilot and the artificial composition of the region's soil including the natural region's soil, sand, and rock stone are used. The leachate, having passed its initial treatment, passed through the soil and to the pilot. It was collected in the end of the pilots and its organic and inorganic contaminants were measured. However, the land treatment of leachate was conducted in a slow rate at various speeds. According to the results, in order to remove COD, BOD5, TDS, TSS, TOC the best result was obtained in the region's soil planted with Vetiver plant and at the speed of $0.2 \mathrm{ml}$ per minute which resulted 99.1\%, 99.7\%, 52.4\%, 98.8\%, 94.9\% removal efficiencies, respectively. It also can be concluded that the higher the organic rate load is, the lower the efficiency of the removal would be. In addition, EC \& pH were measured and the best result was obtained in the region's soil planted with Vetiver plant and at the speed of $0.2 \mathrm{ml} / \mathrm{min}$.
\end{abstract}

Keywords: Land treatment, Leachate, Municipal solid waste, Slow rate irrigation, Contaminant

\section{Background}

One of the most recruited methods to treat waste materials and their disposal is sanitary landfills. This method is used in many countries around the world. Researchers have shown that between 40 to $80 \%$ of municipal solid waste (henceforth MSW) is disposed of in developed countries whereas this rate reaches 60 to $90 \%$ in developing countries [1].

Leachate micro-organisms can be either broken down or absorbed via the process of biological uptake [2]. This process significantly depends on the establishment of microbial populations as a response to the contaminants' loading. It is indispensable to investigate the actual pollution plumes to gain efficient insights into the complicated framework to foresee the fate of the contaminants [3].

Due to Tehran's waste analysis about $68.8 \%$ of the solid waste is biodegradable materials which lead to produce huge amounts of leachate with the high organic

\footnotetext{
* Correspondence: maryam_pzk@yahoo.com

${ }^{1}$ Graduate Faculty of Environment, University of Tehran, Tehran, Iran

Full list of author information is available at the end of the article
}

loads [4,5]. This issue was studied in previous studies which show leachate also contains high volume of inorganic and organic compounds in two phases of suspended or dissolved [6,7]. Hence, leachate is known as hazardous liquid can easily infect the surface water and groundwater [8]. Moreover, as an efficient disposal alternative, leachates are sometimes used for irrigation. This method is appropriate for the polishing of the pretreated leachate [9].

Appropriate treatment of leachate consequently is regarded as a daunting challenge [10]. The occasional existence of highly concentrated heavy metals makes the biological treatment very difficult due to its toxic effects on microbes [11].

It is possible that leachates contain colossal amounts of organic matter in the forms of biodegradable and biorefractory carbon, nitrogen (bio-nitrogen, ammonia, and nitrate nitrogen), heavy metals and etc. [12].

Two systems namely soil and water are known as the natural treatment systems. When the leachate is on the land surface, under controlled conditions, to achieve a

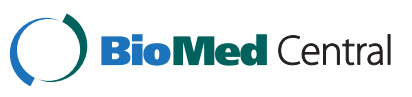


Table 1 Raw leachate's characteristics in Aradkouh's landfill

\begin{tabular}{lccc}
\hline Parameter & Standard methods [18] & Range & Average \pm S.D \\
\hline COD $\left(\mathrm{mg}^{-1}\right)$ & $5220-C O D$ & $40000-70000$ & $50000 \pm 2400$ \\
BOD $_{5}\left(\mathrm{mg}^{-1}\right)$ & $5210-\mathrm{BOD}_{5}$ & $20000-30000$ & $27000 \pm 1700$ \\
TDS $\left(\mathrm{mg}^{-1}\right)$ & $2540-T D S$ & $16500-18000$ & $17000 \pm 500$ \\
TSS $\left(\mathrm{mg}^{-1}\right)$ & $2540-T S S$ & $20300-26200$ & $22000 \pm 4000$ \\
TOC $\left(\mathrm{mg}^{-1}\right)$ & $2310-T O C$ & $16500-20000$ & $18000 \pm 1600$ \\
EC $(\mathrm{ms} / \mathrm{cm})$ & $2510-E C$ & $27.3-33.3$ & $30.6 \pm 3.3$ \\
pH & $4500-H+$ & $4.8-5.1$ & $5 \pm 0.3$ \\
\hline
\end{tabular}

certain level of filtration and treatment through physical, chemical and bio processes in the matrix of water-soilplant, the soil systems are suggested. Moreover, less energy consumption is needed in the land treatment methods rather than the filtration methods which are mostly due to moving and spreading the leachate [13].

In addition, to achieve the best efficiency among the various irrigation methods, regards to the characteristics of the land treatment with leachate, slow irrigation system is presented. Besides, it leads to high removal of contaminants, $\mathrm{BOD}_{5}$ and depositions.

In the land treatment method the pre-treatment process such as screening and primary sedimentation leads to remove suspended solid which prevents damage to irrigation facilities and machinery [14].

Mainly, leachate contains heavy metals. Consequently, a crucial characteristics of plants in phytoremediation needs to be hyper-accumulation. Such type of vegetation is selected due to the physical potential to tolerate and assimilate toxic substances, growing rate, depth of its roots, and capability to degrade or bio accumulate the contaminants in its roots, branches and leaves $[15,16]$.

Using plants in two environments of soil (purification, refinement, preservation, and sustaining soil, sediments) and contaminated waters in previous studies is well accepted [17]. In phyto-remediation methods, one of the significant issues is choosing the kind of the plants. However, plants can lead to water and soil contamination removal and also degrade the bio contaminants. Moreover, they can filter, trap, absorb and stabilize the heavy metals.

Vetiver (Chrysopogonzizanioides) is known as a successfully permanent grass to decline the contaminations due to the mentioned details. It originates from Indian peninsula and for the first time it was used by the World Bank in India [17]. Using Vetiver as a treatment for sewage and leachate was a start point of a great novelty and show the extraordinary capability of plants. In additions, it leads to a green, natural, simple and practical treatment method with low expenses.

The purpose of this study is to evaluate the efficiency of leachate land treatment with the help of Vetiver plant to reduce the COD, $\mathrm{BOD}_{5}$, TSS, TDS and the existing TOC in the leachate in municipal landfills leachate after the pre-treatment stage. Moreover, the above mentioned factors against the current standards are compared and discussed.

\section{Methods}

This research presents the results of a laboratory study in a pilot scale which soil profile as a biological filter to attenuation of organic and inorganic contaminants from landfill's leachate was examined after pre-treatment stage. However, land treatment of leachate in Aradkouh's landfills has been chosen as the study area.

\section{Landfill's characteristics}

Aradkouh's landfill is on the $25^{\text {th }} \mathrm{km}$ of Tehran-Qom road and is used as a disposal facility for more than 40 years. More than 8000 ton solid waste is transported to Aradkouh landfill every day which leads to generate leachate about 637500 liters per day. The underground waters level is very low and the wells have a low rate of discharge between 0.5 to 3 liters per second of salty water.

\section{Raw leachate's characteristics}

The location of sampling effects on the type of leachate. So, fresh leachate is sampled which is needs to sample in

Table 2 The pilot's characteristics

\begin{tabular}{|c|c|c|c|c|}
\hline Tools & Number & Shape & Dimensions & Description \\
\hline \multirow[t]{2}{*}{ Pilot } & \multirow[t]{2}{*}{3} & \multirow[t]{2}{*}{ Cylinder } & Dimeter: $70 \mathrm{~cm}$ & \multirow[t]{2}{*}{ The pilots were filled with the soil up to the $90 \mathrm{~cm}$ of their height } \\
\hline & & & Height: 120 cm & \\
\hline Mushy screen & 3 & Circle & Dimeter: $72 \mathrm{~cm}$ & $\begin{array}{r}\text { at each } 30 \mathrm{~cm} \text { of the pilots, a pipe was implemented in a steep fashion to get the } \\
\text { leachate out }\end{array}$ \\
\hline $\begin{array}{l}\text { Footstool for installing } \\
\text { the pilot }\end{array}$ & 3 & Circle & Dimeter: 72 cm & In the bottom of each pilot, a holed metal plate was used for drainage purposes \\
\hline Reservoir & 1 & Cylinder & Volume: 75 lit & with three output valves \\
\hline \multirow{2}{*}{$\begin{array}{l}\text { Footstool for tank } \\
\text { installation }\end{array}$} & \multirow[t]{2}{*}{1} & \multirow[t]{2}{*}{ Cylinder } & Dimeter: $100 \mathrm{~cm}$ & \multirow[t]{2}{*}{-} \\
\hline & & & Height: 200 cm & \\
\hline
\end{tabular}


the waste discharge place. Usually, these places are dangerous and very hard to take the samples. Otherwise, leachate passes a long way every day and absorb huge amount of contaminants and finally get mixed with the old leachate which leads to lose the initial characteristics. Moreover, the characteristics of generated leachate in Kahrizak's landfill are given in Table 1.

\section{The pilot's characteristics}

In general, three pilots were used and their charecteristics are shown in Table 2. Three various scenarios are conducted to treat the leachate in three pilots. In the first pilot (pilot A), an artificial arrangement soil was used where (from down to top) the first layer is the region soil and the second is sand and rock-stone. On the other hand, the second pilot (pilot B) the natural form of the local soil is used whereas in the third one (pilot C) the local's natural soil planted by Vetiver is used (Figure 1).

\section{Soil analysis}

Physical characteristics of soil such as bulk density, moisture, etc. which are determined according to the standard method of ASTM are presented in Table 3.

As can be indicated, the analysis of the sample soil including the soil texture and composition are given in Table 4.

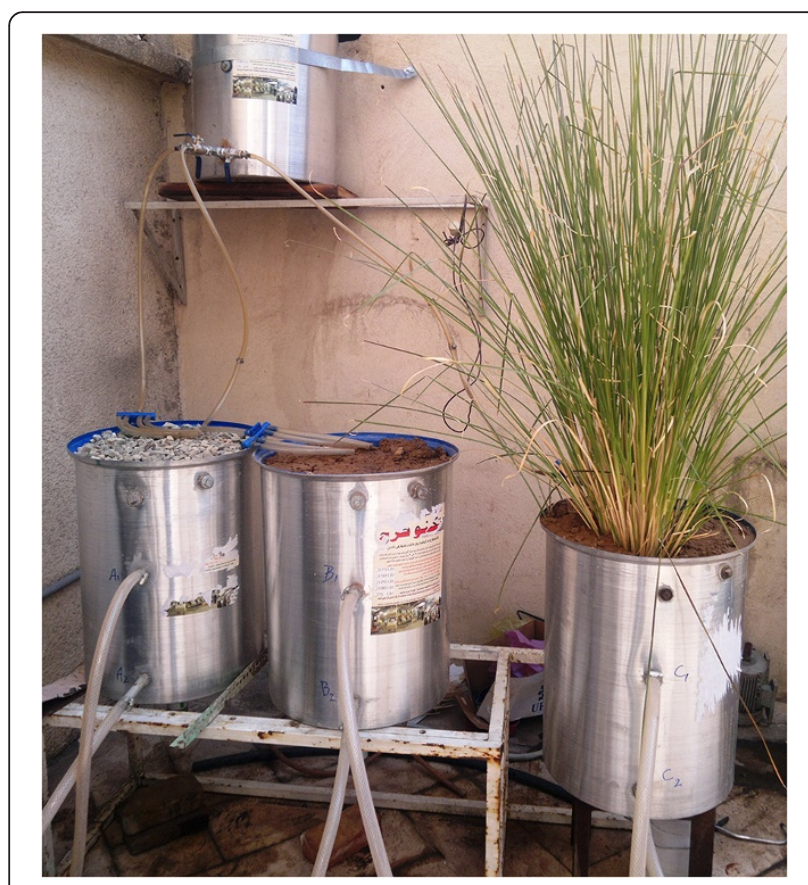

Figure 1 Stages leachate movements from storage to pilots.
Table 3 The results of soil studied in Aradkouh's landfill

\begin{tabular}{lccccc}
\hline Bulk density & $\mathbf{K}(\mathbf{c m ~ s}-\mathbf{1})$ & $\boldsymbol{\omega} \%$ & $\mathbf{p H}$ & $\mathrm{EC}(\mathbf{m s} / \mathbf{c m})$ & TDS (g/lit) \\
\hline 1.86 & $1.56 \times 10^{-6}$ & 13 & 8.2 & 10.01 & 5.2 \\
\hline
\end{tabular}

\section{Initial preparation and irrigation}

Irrigation technique for forming the structure of soil was conducted for six weeks. The soil underwent wet and dry periods. After that, the output leachate from anaerobic lagoons with a retention time of one month is replaced for irrigation. To achieve the slow rate irrigation leachate sprayed in three rates $(0.2,0.6$ and $1 \mathrm{ml} / \mathrm{min})$. However, the process is done at a certain filtration rate and at specific time intervals according to the of slow rate irrigation's form.

\section{Laboratory analysis}

For running the laboratory tests, the sampling was conducted twice a week. Moreover, to prevent anaerobic conditions the pilots are irrigated with three days interval between irrigations. The samples from the pilots were gathered three times at each rate of 0.2, 0.6 and $1 \mathrm{ml} / \mathrm{min}$, respectively. After that, the output sewage liquids were tested to estimate the COD, $\mathrm{BOD}_{5}$, TDS, TSS, TOC and EC. To determine the level of reduction done by soil and plant the results were compared to the pretreatment stage. It should be mentioned that, the experiments were conducted according to the APHA standard [18]. In addition, to avoid any change in $\mathrm{pH}$ values while $\mathrm{pH}$-meter is used due to the $\mathrm{CO}_{2}$ evolution, $\mathrm{pH}$ was determined immediately after the sampling ( $\mathrm{pH}$ Tutor, Mfg. by: Eutech Instruments). All the experiments were carried out three times and the mean values are used in this report.

\section{Statistical analysis}

To analysis the results the Duncan test was used. Duncan test can be applied when the number of samples is more than three. In this test, the significant level of $(\alpha=0.05)$ is assumed.

\section{Results and discussion}

\section{$\mathrm{pH}$, conductivity and TDS}

In this section, the results of the experiments which were conducted in various rates and heights or the three considered pilots are presented and discussed in Tables 5,

Table 4 Composition of soil studied

\begin{tabular}{lcc}
\hline Composition & Test method (ASTM, 2001) & Measured value (\%) \\
\hline Clay and gravel & ASTM-D422 & 63.62 \\
percentage & \\
Sand percentage & 33.59 \\
Silt percentage & 2.79 \\
\hline
\end{tabular}


Table 5 The results of the experiment at the rate of $0.2 \mathrm{ml} / \mathrm{min}$

\begin{tabular}{|c|c|c|c|c|c|c|c|c|c|c|}
\hline \multirow[t]{2}{*}{ Parameter } & \multirow{2}{*}{$\begin{array}{c}\text { Input } \\
\text { Average }\end{array}$} & \multicolumn{3}{|c|}{ Pilot A } & \multicolumn{3}{|c|}{ Pilot B } & \multicolumn{3}{|c|}{ Pilot C } \\
\hline & & $O_{1}$ & $\mathrm{O}_{2}$ & $\mathrm{O}_{3}$ & $O_{1}$ & $\mathrm{O}_{2}$ & $\mathrm{O}_{3}$ & $O_{1}$ & $\mathrm{O}_{2}$ & $\mathrm{O}_{3}$ \\
\hline $\mathrm{EC}(\mathrm{ms} / \mathrm{cm})$ & 8700 & 8340 & 8270 & 6712 & 7345 & 5900 & 4670 & 6780 & 5630 & 4123 \\
\hline $\mathrm{pH}$ & 6.13 & 6.51 & 7.87 & 7.12 & 7.6 & 7.6 & 7.9 & 7.14 & 7.01 & 7.02 \\
\hline TDS (mg/l) & 4540 & 4360 & 4200 & 3360 & 3810 & 3080 & 2300 & 3500 & 2930 & 2160 \\
\hline
\end{tabular}

Table 6 The results of the experiment at the rate of $0.6 \mathrm{ml} / \mathrm{min}$

\begin{tabular}{|c|c|c|c|c|c|c|c|c|c|c|}
\hline \multirow[t]{2}{*}{ Parameter } & \multirow{2}{*}{$\begin{array}{c}\text { Input } \\
\text { Average }\end{array}$} & \multicolumn{3}{|c|}{ Pilot A } & \multicolumn{3}{|c|}{ Pilot B } & \multicolumn{3}{|c|}{ Pilot C } \\
\hline & & $O_{1}$ & $\mathrm{O}_{2}$ & $\mathrm{O}_{3}$ & $O_{1}$ & $\mathrm{O}_{2}$ & $\mathrm{O}_{3}$ & $O_{1}$ & $\mathrm{O}_{2}$ & $\mathrm{O}_{3}$ \\
\hline $\mathrm{EC}(\mathrm{ms} / \mathrm{cm})$ & 8512 & 8005 & 7912 & 6634 & 7623 & 5834 & 4934 & 6891 & 5345 & 3798 \\
\hline $\mathrm{pH}$ & 6.8 & 6.8 & 7.3 & 7.7 & 6.9 & 7.2 & 7.7 & 6.8 & 7.4 & 7.6 \\
\hline TDS (mg/l) & 4430 & 4250 & 4136 & 3332 & 3960 & 3100 & 2450 & 3667 & 2900 & 2316 \\
\hline
\end{tabular}

6 and 7. In each $30 \mathrm{~cm}$ from the top to down of each pilots an output sample was tested which we name them $\mathrm{O}_{1}, \mathrm{O}_{2}$ and $\mathrm{O}_{3}$. It should be mentioned that the input of the pilots was the output of pre-treatment section.

Due to the Tables 5, 6 and 7 the rate of EC decline in various rates for all the pilots was determined. The best efficiency was obtained at the medium rate $(0.2 \mathrm{ml} / \mathrm{min})$ at pilot $\mathrm{C}$ for the sample $\mathrm{O}_{3}$. Moreover, the amount of TDS was decreased along the soil profile. However, the maximum reduction rate was obtained at the medium rate of $0.2 \mathrm{ml} / \mathrm{min}$ at pilot $\mathrm{C}$ for the sample $\mathrm{O}_{3}$. This can be defined by passing the leachate throw the various layer of the soil, biomasses are being formed which lead to the adsorption of some ions by the soil and decrease the TDS.

With regards to the achieved P-value, the amount of EC and TDS are 0.015 and 0.044 , respectively. According to the assumed $\alpha=0.05$, the $p$-value is less than $\alpha$ which implies that with varying the flow rate and the pilots cause negligible changes to amounts of EC and TDS.

\section{$\mathrm{COD} \& \mathrm{BOD}_{5}$}

Tables $8,9,10$ present the $\mathrm{COD}$ and $\mathrm{BOD}_{5}$ values which were determined due to various rates in the three studied pilots.

The output $\mathrm{COD}$ and $\mathrm{BOD}_{5}$ values due to various rates in the three studied pilots are shown in Figures 2 and 3 which were compared with standards discharging to surface waters, agricultural purposes and irrigation.

With respect to the Tables 8, 9 and 10, the variation of $\mathrm{COD}$ and $\mathrm{BOD}_{5}$ values due to different rates for each samples are illustrated. Moreover, the special trends are shown and discussed in following. The best efficiency was reached at the medium rate $(0.2 \mathrm{ml} / \mathrm{min})$ at the pilot $\mathrm{C}$ for the sample $\mathrm{O}_{3}$. Moreover, the output results at the speed of $0.2 \mathrm{ml} / \mathrm{min}$ at the pilot $\mathrm{C}$ for the sample $\mathrm{O}_{3}$

Table 7 The results of the experiment at the rate of $1 \mathrm{ml} / \mathrm{min}$

\begin{tabular}{|c|c|c|c|c|c|c|c|c|c|c|}
\hline \multirow[t]{2}{*}{ Parameter } & \multirow{2}{*}{$\begin{array}{c}\text { Input } \\
\text { Average }\end{array}$} & \multicolumn{3}{|c|}{ Pilot A } & \multicolumn{3}{|c|}{ Pilot B } & \multicolumn{3}{|c|}{ Pilot C } \\
\hline & & $O_{1}$ & $\mathrm{O}_{2}$ & $\mathrm{O}_{3}$ & $O_{1}$ & $\mathrm{O}_{2}$ & $\mathrm{O}_{3}$ & $O_{1}$ & $\mathrm{O}_{2}$ & $\mathrm{O}_{3}$ \\
\hline $\mathrm{EC}(\mathrm{ms} / \mathrm{cm})$ & 8576 & 8367 & 8100 & 7111 & 7789 & 7083 & 5902 & 7498 & 6127 & 5101 \\
\hline $\mathrm{pH}$ & 6.6 & 6.7 & 6.7 & 7.1 & 6.8 & 7.3 & 7.4 & 7.1 & 7.2 & 7.4 \\
\hline TDS (mg/l) & 4480 & 4320 & 4212 & 3785 & 4120 & 3751 & 2919 & 3928 & 3307 & 2685 \\
\hline
\end{tabular}

Table 8 The results of the experiment at the rate of $0.2 \mathrm{ml} / \mathrm{min}$

\begin{tabular}{|c|c|c|c|c|c|c|c|c|c|c|}
\hline \multirow[t]{2}{*}{ Parameter } & \multirow{2}{*}{$\begin{array}{c}\text { Input } \\
\text { average (mg/l) }\end{array}$} & \multicolumn{3}{|c|}{ Pilot A } & \multicolumn{3}{|c|}{ Pilot B } & \multicolumn{3}{|c|}{ Pilot C } \\
\hline & & $\mathrm{O}_{1}$ & $\mathrm{O}_{2}$ & $\mathrm{O}_{3}$ & $\mathrm{O}_{1}$ & $\mathrm{O}_{2}$ & $\mathrm{O}_{3}$ & $\mathrm{O}_{1}$ & $\mathrm{O}_{2}$ & $\mathrm{O}_{3}$ \\
\hline $\mathrm{COD}(\mathrm{mg} / \mathrm{l})$ & 3840 & 3560 & 1120 & 156 & 2010 & 534 & 82 & 834 & 301 & 35 \\
\hline COD removal (\%) & - & 7.3 & 71 & 96 & 47.7 & 86.1 & 97.9 & 78.3 & 92.2 & 99.1 \\
\hline $\mathrm{BOD}_{5}(\mathrm{mg} / \mathrm{l})$ & 1370 & 1210 & 456 & 54 & 712 & 132 & 14 & 291 & 91 & 4 \\
\hline $\mathrm{BOD}_{5}$ removal (\%) & - & 11.7 & 66.7 & 96.1 & 48 & 90.4 & 99 & 78.8 & 93.4 & 99.8 \\
\hline $\mathrm{BOD}_{5} / \mathrm{COD}$ & 0.36 & 0.34 & 0.41 & 0.35 & 0.35 & 0.25 & 0.17 & 0.35 & 0.30 & 0.11 \\
\hline
\end{tabular}


Table 9 The results of the experiment at the rate of $0.6 \mathrm{ml} / \mathrm{min}$

\begin{tabular}{|c|c|c|c|c|c|c|c|c|c|c|}
\hline \multirow[t]{2}{*}{ Parameter } & \multirow{2}{*}{$\begin{array}{c}\text { Input } \\
\text { average (mg/l) }\end{array}$} & \multicolumn{3}{|c|}{ Pilot A } & \multicolumn{3}{|c|}{ Pilot B } & \multicolumn{3}{|c|}{ Pilot C } \\
\hline & & $\mathrm{O}_{1}$ & $\mathrm{O}_{2}$ & $\mathrm{O}_{3}$ & $O_{1}$ & $\mathrm{O}_{2}$ & $\mathrm{O}_{3}$ & $O_{1}$ & $\mathrm{O}_{2}$ & $\mathrm{O}_{3}$ \\
\hline $\mathrm{COD}(\mathrm{mg} / \mathrm{l})$ & 3700 & 3680 & 1900 & 467 & 3360 & 1080 & 345 & 1020 & 512 & 243 \\
\hline COD removal (\%) & - & 0.6 & 48.7 & 87.4 & 9.2 & 70.8 & 90.7 & 72.4 & 86.2 & 93.4 \\
\hline $\mathrm{BOD}_{5}(\mathrm{mg} / \mathrm{l})$ & 1320 & 1270 & 558 & 101 & 979 & 274 & 61 & 354 & 143 & 35 \\
\hline $\mathrm{BOD}_{5}$ removal $(\%)$ & - & 3.8 & 57.7 & 92.4 & 25.8 & 79.2 & 95.4 & 73.2 & 86.16 & 97.4 \\
\hline $\mathrm{BOD}_{5} / \mathrm{COD}$ & 0.36 & 0.35 & 0.29 & 0.22 & 0.29 & 0.25 & 0.18 & 0.35 & 0.28 & 0.14 \\
\hline
\end{tabular}

Table 10 The results of the experiment at the rate of $1 \mathrm{ml} / \mathrm{min}$

\begin{tabular}{|c|c|c|c|c|c|c|c|c|c|c|}
\hline \multirow[t]{2}{*}{ Parameter } & \multirow{2}{*}{$\begin{array}{c}\text { Input } \\
\text { average (mg/l) }\end{array}$} & \multicolumn{3}{|c|}{ Pilot A } & \multicolumn{3}{|c|}{ Pilot B } & \multicolumn{3}{|c|}{ Pilot C } \\
\hline & & $\mathrm{O}_{1}$ & $\mathrm{O}_{2}$ & $\mathrm{O}_{3}$ & $\mathrm{O}_{1}$ & $\mathrm{O}_{2}$ & $\mathrm{O}_{3}$ & $\mathrm{O}_{1}$ & $\mathrm{O}_{2}$ & $\mathrm{O}_{3}$ \\
\hline $\mathrm{COD}(\mathrm{mg} / \mathrm{l})$ & 3800 & 3756 & 2843 & 696 & 3667 & 1993 & 583 & 1437 & 809 & 435 \\
\hline COD removal (\%) & - & 1.2 & 25.2 & 81.7 & 3.5 & 47.6 & 84.7 & 62.2 & 78.7 & 88.6 \\
\hline $\mathrm{BOD}_{5}(\mathrm{mg} / \mathrm{l})$ & 1330 & 1306 & 874 & 126 & 1243 & 589 & 96 & 493 & 256 & 59 \\
\hline $\mathrm{BOD}_{5}$ removal (\%) & - & 1.8 & 34.3 & 90.5 & 6.5 & 55.7 & 92.8 & 63 & 80.8 & 95.6 \\
\hline $\mathrm{BOD}_{5} / \mathrm{COD}$ & 0.35 & 0.35 & 0.31 & 0.18 & 0.34 & 0.3 & 0.17 & 0.34 & 0.32 & 0.14 \\
\hline
\end{tabular}

meets the both standards discharging to surface waters and agricultural purposes and irrigation.

Along the soil profile the amounts of $\mathrm{COD}$ and $\mathrm{BOD}_{5}$ were declined. Some parts of particulate COD were decreased by the mechanism of sedimentation and colloidal material adsorbed and then deposited. Some parts of organic materials were reduced by anaerobic decomposition mechanism. $\mathrm{BOD}_{5} / \mathrm{COD}$ ratio was decreased, because microorganisms that were present in the biofilm layer consumed organic matter, also biodegradable organic matter was decomposed thus this ratio is reduced.

In addition, the most elimination rate is founded in the pilot $\mathrm{A}$ at the first $30 \mathrm{~cm}\left(\mathrm{O}_{1}\right)$, all the three flow rates. However, as much as the soil aggregation gets finer the retention time and the elimination efficiency increased more.
As can be seen, if the organic loading gets more intense (increase the input flow rate), the percentage of removal efficiency would decreases due to the declination of the hydraulic retention time which leads to descend the rate of reduction.

In pilot $C$ in addition to the natural soil zone, the plant growth with the spray roots is effective in the elimination of leachate pollutants. The plant growth regards to the Rhizosphere which is the gathering place of microorganisms and the level of the biological activities are high, with the coexistence between the microorganisms and the absorption of plant roots, lead to more elimination of the leachate pollutants.

The p-values for the COD and the BOD5 are 0.28 and 0.411 , respectively. However, it can be concluded that

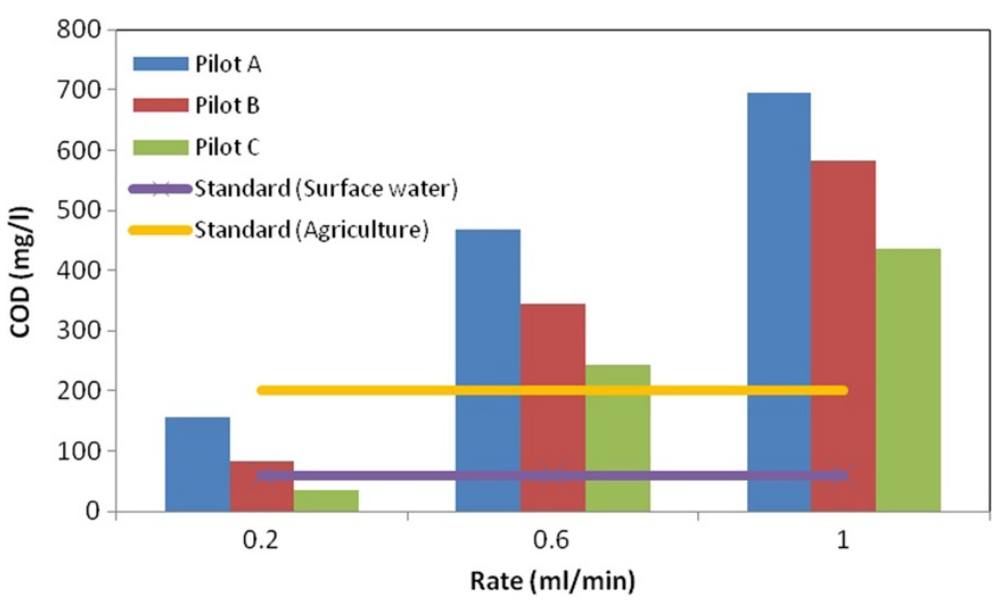

Figure 2 COD values due to various rates. 


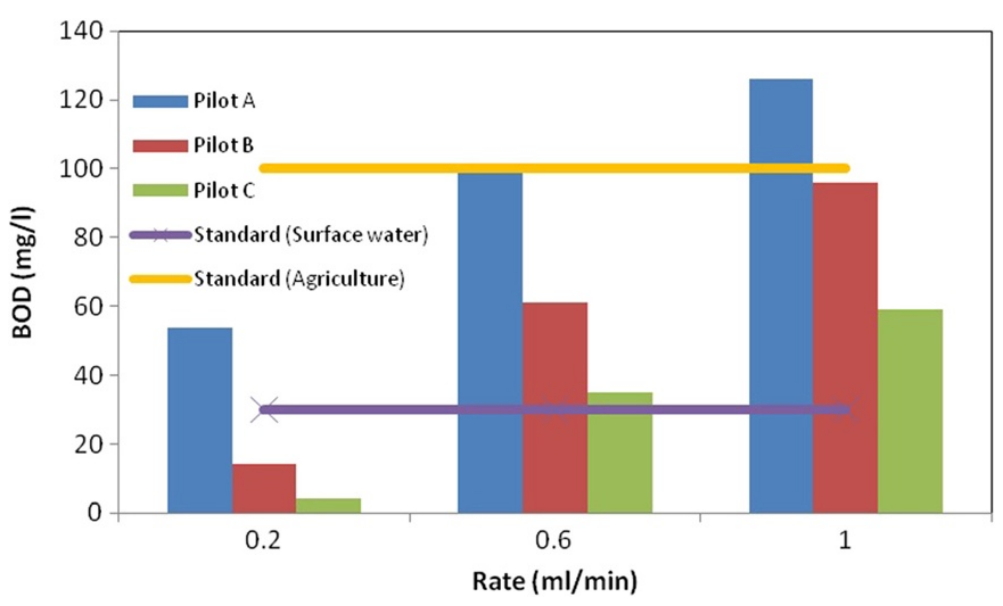

Figure 3 BOD5 values due to various rates.

due to varying the flow rates and the pilots the amounts of COD and BOD5 are fluctuated.

\section{TSS \& TOC}

Tables 11, 12, 13 show the results of TSS and TOC which were measured for the outputs of the three pilots due to the various speed ratios.

The measured values of TSS for the samples due to different speed ratios are illustrated in Due to the Tables 11, 12, 13, the best efficiency was achieved at the medium rate of $0.2 \mathrm{ml} / \mathrm{min}$ in the sample of $\mathrm{O}_{3}$ at pilot C. Moreover, TOC along the profile of soil was decreased and the maximum reduction caused at the medium speed ratio of $0.2 \mathrm{ml} / \mathrm{min}$ at sample $\mathrm{O}_{3}$ at pilot C. To sum up, the best efficiency was obtained at the pilot $\mathrm{C}$, sample $\mathrm{O}_{3}$ whilst the average amounts of TSS and TOC removal were \%98.2 and \%94.9.

The solid suspended materials are separated before the other materials caused by the flowing throw the soil. A proportion of TSS is eliminated by the screening and sedimentation mechanism and another proportion of fine, soluble and colloidal materials are adsorbed. However, due to the low flow rate the sedimentation is increased. It should be mentioned that, in the systems with rapid penetration most of the solid materials are separated in the surface of the soil. Therefore, it would be possible that the wastewater materials blocking the surface. Hence, drainage systems are suggested.

As can be seen in the above tables, growth in the load of organic materials leads to decrease the elimination efficiency which is caused by increasing the retention time.

Table 11 The results of the experiment at the rate of $0.2 \mathrm{ml} / \mathrm{min}$

\begin{tabular}{|c|c|c|c|c|c|c|c|c|c|c|}
\hline \multirow[t]{2}{*}{ Parameter } & \multirow{2}{*}{$\begin{array}{c}\text { Input } \\
\text { average (mg/l) }\end{array}$} & \multicolumn{3}{|c|}{ Pilot A } & \multicolumn{3}{|c|}{ Pilot B } & \multicolumn{3}{|c|}{ Pilot C } \\
\hline & & $\overline{O_{1}}$ & $\mathrm{O}_{2}$ & $\overline{\mathrm{O}_{3}}$ & $\mathrm{O}_{1}$ & $\mathrm{O}_{2}$ & $\mathrm{O}_{3}$ & $O_{1}$ & $\mathrm{O}_{2}$ & $\mathrm{O}_{3}$ \\
\hline TSS (mg/l) & 680 & 380 & 152 & 16 & 212 & 87 & 11 & 230 & 112 & 8 \\
\hline TSS removal (\%) & - & 44.1 & 77.7 & 97.7 & 68.8 & 87.2 & 98.4 & 66.2 & 83.5 & 98.2 \\
\hline TOC (mg/l) & 860 & 730 & 426 & 67 & 602 & 365 & 57 & 532 & 108 & 44 \\
\hline TOC removal (\%) & - & 15.1 & 50.5 & 92.2 & 30 & 57.6 & 93.4 & 38.1 & 87.4 & 94.9 \\
\hline
\end{tabular}

Table 12 The results of the experiment at the rate of $0.6 \mathrm{ml} / \mathrm{min}$

\begin{tabular}{|c|c|c|c|c|c|c|c|c|c|c|}
\hline \multirow[t]{2}{*}{ Parameter } & \multirow{2}{*}{$\begin{array}{c}\text { Input } \\
\text { average (mg/l) }\end{array}$} & \multicolumn{3}{|c|}{ Pilot A } & \multicolumn{3}{|c|}{ Pilot B } & \multicolumn{3}{|c|}{ Pilot C } \\
\hline & & $\mathrm{O}_{1}$ & $\mathrm{O}_{2}$ & $\mathrm{O}_{3}$ & $\mathrm{O}_{1}$ & $\mathrm{O}_{2}$ & $\mathrm{O}_{3}$ & $\mathrm{O}_{1}$ & $\mathrm{O}_{2}$ & $\mathrm{O}_{3}$ \\
\hline TSS (mg/l) & 710 & 415 & 178 & 44 & 336 & 75 & 29 & 340 & 53 & 18 \\
\hline TSS removal (\%) & - & 41.6 & 74.9 & 93.8 & 52.7 & 89.4 & 95.9 & 52.1 & 92.5 & 97.5 \\
\hline TOC (mg/l) & 845 & 742 & 510 & 87 & 738 & 465 & 78 & 770 & 398 & 70 \\
\hline TOC removal (\%) & - & 12.2 & 39.6 & 89.7 & 12.7 & 45 & 90.8 & 8.9 & 52.9 & 91.7 \\
\hline
\end{tabular}


Table 13 The results of the experiment at the rate of $1 \mathrm{ml} / \mathrm{min}$

\begin{tabular}{|c|c|c|c|c|c|c|c|c|c|c|}
\hline \multirow[t]{2}{*}{ Parameter } & \multirow{2}{*}{$\begin{array}{c}\text { Input } \\
\text { average (mg/l) }\end{array}$} & \multicolumn{3}{|c|}{ Pilot A } & \multicolumn{3}{|c|}{ Pilot B } & \multicolumn{3}{|c|}{ Pilot C } \\
\hline & & $\mathrm{O}_{1}$ & $\mathrm{O}_{2}$ & $\mathrm{O}_{3}$ & $O_{1}$ & $\mathrm{O}_{2}$ & $\mathrm{O}_{3}$ & $\mathrm{O}_{1}$ & $\mathrm{O}_{2}$ & $\mathrm{O}_{3}$ \\
\hline TSS (mg/l) & 692 & 456 & 216 & 77 & 401 & 102 & 56 & 369 & 98 & 38 \\
\hline TSS removal (\%) & - & 34.1 & 68.8 & 88.9 & 42.1 & 85.3 & 91.9 & 46.7 & 85.8 & 94.5 \\
\hline TOC (mg/l) & 860 & 750 & 580 & 123 & 760 & 430 & 113 & 738 & 412 & 99 \\
\hline TOC removal (\%) & - & 12.8 & 32.6 & 85.7 & 11.6 & 50 & 86.9 & 14.2 & 52.1 & 88.5 \\
\hline
\end{tabular}

As can be seen, in Table 14 a brief literature review of attenuation of landfill leachate with compared to the results of this study is given.

\section{Conclusions}

In this research the capability of land filtration and treatment in natural reduction of organic and inorganic contaminants existing in the leachate after the pretreatment stage was studied. Based on comparison of the results a few points can be concluded which are presented as follows.

1. Land treatment of leachate has a significant positive effect on COD removal and $\mathrm{pH}$ stabilization. Due to the achieved results of pilot $\mathrm{C}\left(\mathrm{Sample}_{3}\right)$ at the rate of $0.2 \mathrm{ml} / \mathrm{min}$ the maximum reduction efficiency including $\mathrm{COD}, \mathrm{BOD}_{5}$, TSS \& $\mathrm{TOC}$ at $99.1 \%$, 99.7\%, 98.2\% \& 94.9\% were obtained, respectively.
2. The higher the organic rate load is, the lower the efficiency of the removal would be. In lower hydraulic loads, the reduction rate of organic and inorganic contaminant due to the longer hydraulic retention time is more.

3. Using Vetiver plant in land treatment and filtration of leachate increases the efficiency. It also plays a key role in the contaminant reduction at an appropriate rate (to remove organic and inorganic contaminant, pre-treatment is essential which leads to increase the expenses).

4. This filtration technique compared to the advanced filtration methods, only needs to transmit the leachate from output of the initial sedimentation system, spreading and spraying it on the surface requires energy. Moreover, it needs less mechanical facilities. Also, it requires lower and easier levels of maintenance.

Table 14 Literature data of land treatment techniques for reduction of organic material

\begin{tabular}{|c|c|c|}
\hline Operation condition & Results & Authors/date \\
\hline $\begin{array}{l}\text { Landfill leachate, leachate irrigation of woodland, } \\
\text { full scale }\end{array}$ & $\begin{array}{l}\text { Leachate concentrations of up to } 1500 \mathrm{mg} \mathrm{BOD} 5 / \mathrm{I} \text { and } 300 \mathrm{mg} \mathrm{NH} 4 \\
\text { C-N/l, have been spray irrigated to woodland at appropriate loadings } \\
\text { that show no detrimental effects on the irrigated vegetation; }\end{array}$ & $\begin{array}{l}\text { Cornwall County } \\
\text { Council [19]. }\end{array}$ \\
\hline $\begin{array}{l}\text { Pilot-scale, land treatment system, treated } \\
\text { wastewater from the stabilization pond system of } \\
\text { the latex factory }\end{array}$ & $\begin{array}{l}\text { The average removal efficiency of TKN, NH3-N, Org-N, BOD5 and sulfate } \\
\text { for tropical carpet grass unit were } 92,97,61,88 \text { and } 52 \% \text {, for water } \\
\text { convolvulus unit were } 75,80,43,41 \text { and } 30 \% \text {, and for control unit were } \\
74,80,41,31 \text { and } 28 \% \text {, respectively. }\end{array}$ & $\begin{array}{l}\text { Thongnuekhang V. } \\
\text { and Puetpaiboon. U. } \\
\text { [20]. }\end{array}$ \\
\hline $\begin{array}{l}\text { Landfill leachate as irrigation water for tree and } \\
\text { vegetable, full scale }\end{array}$ & $\begin{array}{l}\text { The effects of landfill leachate on the growth of tree and vegetable } \\
\text { crops were studied with 5, 10, } 20 \text { and } 40 \% \text { leachate dilutions than in } \\
\text { the non-leachate control. Leachate-treated soil had elevated levels of } \\
\text { electrical conductivity, total-, ammonia) and nitrate-N, exchangeable } \\
\text { Na and P. }\end{array}$ & $\begin{array}{l}\text { Wong M. H. and } \\
\text { Leung C. K. [21]. }\end{array}$ \\
\hline $\begin{array}{l}\text { Young synthetic acetogenic phase landfill leachate, } \\
\text { at two hydraulic loading rates (HLR). }\end{array}$ & $\begin{array}{l}\text { The results presented suggest that the HLR of leachate into soil arrays } \\
\text { contributes to significant differences in the fate of the landfill leachate } \\
\text { parameters (phenol, copper, and zinc) earlier }\end{array}$ & $\begin{array}{l}\text { Kamenthren } \\
\text { Govender [22]. }\end{array}$ \\
\hline $\begin{array}{l}\text { Three-year field study, intensive leachate irrigation } \\
\text { of two willow varieties }\end{array}$ & $\begin{array}{l}\text { Two willow varieties were tested and four irrigation regimes in sixteen } \\
400-\mathrm{m} 2 \text { plots. The willow plants did not react negatively, despite very } \\
\text { high annual loads of nitrogen, chloride and other elements. }\end{array}$ & $\begin{array}{l}\text { Aronsson P. Dahlin } \\
\text { T. Dimitriou I. [23]. }\end{array}$ \\
\hline $\begin{array}{l}\text { Landfill leachate, leachate irrigation of grass and } \\
\text { willows, full scale }\end{array}$ & $\begin{array}{l}\text { leachate input ( } 400 \mathrm{~m} 3 \text { per month per hectare in average) did not } \\
\text { result in excessive accumulation of salts, heavy metals, or nutrients, } \\
\text { which could negatively affect soil properties and plant growth }\end{array}$ & $\begin{array}{c}\text { Justin M. Z. Zupanc } \\
\text { M. [24]. }\end{array}$ \\
\hline $\begin{array}{l}\text { Pilot plant scale, Landfill leachate, land treatment, } \\
\text { slow rate irrigation, three rate } 0.2,0.6 \text { and } 1 \mathrm{ml} / \mathrm{min}\end{array}$ & $\begin{array}{l}\text { in order to remove COD, BOD5, TDS, TSS, TOC the best result was } \\
\text { obtained in the region's soil planted with Vetiver plant and at the } \\
\text { speed of } 0.2 \mathrm{ml} \text { per minute which resulted } 99.1 \%, 99.7 \%, 52.4 \%, 98.8 \% \text {, } \\
94.9 \% \text { removal efficiencies, respectively }\end{array}$ & This study \\
\hline
\end{tabular}




\section{Competing interests}

The authors declare that they have no competing interests.

\section{Authors' contributions}

All authors contributed to the manuscript. All persons listed as authors have read, contributed to preparing the manuscript and attest to the validity and legitimacy of the data and its interpretation, and agree to its submission to Iranian Journal of Environmental Health Science \& Engineering. No person more than the authors listed have contributed significantly to its preparation. All authors read and approved the final manuscript.

\section{Acknowledgements}

The project was supported by Pars Special Economic Energy Zone, I would like to express my gratitude for their supporting and technical help.

\section{Author details}

${ }^{1}$ Graduate Faculty of Environment, University of Tehran, Tehran, Iran. ${ }^{2}$ Department of Environmental Health Engineering, School of Public Health, Tehran University of Medical Sciences, Tehran, Iran.

Received: 16 October 2012 Accepted: 22 October 2013

Published: 7 January 2014

\section{References}

1. EEA (European Environment Agency): Diverting waste from landfill: effectiveness of waste-management policies in the European union: office for official publications of the European communities, report no 7. Brussels, Belgium: EEA; 2009. doi:10.2800/10886.

2. Bagchi A: Design, construction, and monitoring of landfills. New York, USA: John Wiley and Sons; 1994.

3. Williams GM, Higgo JJW: In situ and laboratory investigations into contaminant migration. J Hydrol 1994, 159:1-25.

4. Abdoli MA, Karbassi AR, Samiee-Zafarghandi R, Rashidi ZH, Gitipour S, Pazoki M: Electricity generation from leachate treatment plant. Int J Environ Res 2012, 6(2):493-498.

5. Rashidi ZH, Karbassi AR, Ataei A, Ifaei P, Samiee-Zafarghandi R, Mohammadizadeh MJ: Power plant design using gas produced by waste leachate treatment plant. Int J Environ Res 2012, 6(4):875-882.

6. Bilgili MS, Demir A, Akkaya E, Ozkaya B: COD fractions of leachate from aerobic and anaerobic pilot scale landfill reactors. J Hazard Mater 2008, 158(1):157-163.

7. Qygard JK, Gjengedal E: Uranium in municipal solid waste landfill leachate. Int J Environ Res 2008, 3(1):61-68.

8. Maqbool F, Bhatti ZA, Malik AH, Pervez A, Mahmood Q: Effect of landfill leachate on the stream water quality. Int J Environ Res 2011, 5(2):491-500.

9. Gray D, Pollard SJT, Spence L, Smith R, Gronow JR: Spray irrigation of landfill leachate: estimating potential exposures to workers and bystanders using a modified air box model and generalized source term. Environ Pollut 2005, 133:587-599.

10. Neczaj E, Okoniewska E, Kacprzak M: Treatment of landfill leachate by sequencing batch reactor. Desalinat 2005, 185:357-362.

11. Sawaittayothin $V$, Polprasert C: Nitrogen mass balance and microbial analysis of constructed wetlands treating municipal landfill leachate. Bioresour Technol 2007, 98:565-570.

12. Yilmaz T, Apaydin Se A, Berktay: Coagulation-flocculation and air stripping as a pretreatment of young landfill leachate. Open Environ Eng J 2010, 3:42-48.

13. Crites RW, Middlebrooks J, Reed SC: Natural wastewater treatment systems. LLC: Taylor \& Francis group; 2006.

14. Crites RW, Reed SC, Bastian RK: Land treatment systems for municipal and industrial wastes. New York: McGraw-Hill; 2008.

15. Salt DE, Smith RD, Raskin J: Phytoremediation: annual review plant physiology. Plant Mol Biol 1998, 49:643-668.

16. Barcelo J, Poschenrieder C: Phytoremediation: principles and perspectives. Contrib Sci 2003, 2(3rd):333-344.

17. Truong P: Research and development of the Vetiver system for treatment of polluted water and contaminated land. Cochin, India: First Indian national Vetiver workshop; 2008.

18. American Public Health Association (APHA): Standard methods for the examination of water and wastewater. 22nd edition. Washington D C; 2012.
19. Cornwall County Council: A manual of good practice for leachate treatment by irrigation to land-summary report. UK: Cornwall County Council Waste Regulation Authority for the Department of the Environment; 1994:54.

20. Thongnuekhang $V$, Puetpaiboon U: Nitrogen removal from concentrated latex wastewater by land treatment. 2004.

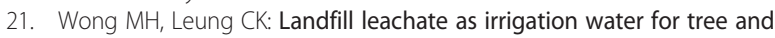
vegetable crops. Waste Manage Res 1989, 7:311-324.

22. Govender K: An assessment of synthetic landfill leachate attenuation in soil and the spatial and temporal implications of the leachate on bacterial community diversity, thesis for the Degree of Master of Science in Agriculture. South Africa: University of KwaZulu-Natal; 2008.

23. Aronsson P, Dahlin T, Dimitriou I: Treatment of landfill leachate by irrigation of willow coppice-plant response and treatment efficiency. Environ Pollut 2010, 158:795-804.

24. Justin MZ, Zupanc M: Combined purification and reuse of landfill leachate by constructed wetland and irrigation of grass and willows. Desalination 2009, 247:158-169.

doi:10.1186/2052-336X-12-12

Cite this article as: Pazoki et al:: Attenuation of municipal landfill leachate through land treatment. Journal of Environmental Health Sciences \& Engineering 2014 12:12.

\section{Submit your next manuscript to BioMed Central and take full advantage of:}

- Convenient online submission

- Thorough peer review

- No space constraints or color figure charges

- Immediate publication on acceptance

- Inclusion in PubMed, CAS, Scopus and Google Scholar

- Research which is freely available for redistribution

Submit your manuscript at www.biomedcentral.com/submit
C BioMed Central 